\title{
Cultural Heritage and Flood Need of Interdisciplinarity
}

\author{
Klára Nedvědová \\ Institute of Theoretical and Applied Mechanics, Academy of Sciences of the Czech Republic, Prague, Czech Republic \\ Email: nedvedova@gmail.com
}

Received February 19, 2013; revised March 20, 2013; accepted April 5, 2013

Copyright (C) 2013 Klára Nedvědová. This is an open access article distributed under the Creative Commons Attribution License, which permits unrestricted use, distribution, and reproduction in any medium, provided the original work is properly cited.

\begin{abstract}
This contribution discusses some results of the ongoing research focused on the protection of cultural heritage from flood danger. The research project Methodology of Protection and Rescue of Cultural Heritage against Flood takes place in the Czech Republic and is focused on specific regional problems that have been experienced during and after disastrous floods in past 15 years. However, the lessons learned have wider applicability to the issue of flood protection of cultural heritage. Here, we describe two case studies that represent important issues requiring a solution; addressing these issues was the main motivation for the whole project.
\end{abstract}

Keywords: Cultural Heritage; Flood; Interdisciplinarity; Flood Protection System

\section{Introduction}

Flood is a natural phenomenon that cannot be avoided; however, in past years due to climate changes and changes in water management, its impact is rapidly growing. During the last 15 years we have experienced many severe flooding events that influenced almost every part of the Czech Republic. In addition to damage to life and property, there has been loss of historical monuments, devastation of sites and changes in the historical landscape. Cultural heritage forms a special category that usually requires a unique and individual approach because its assets cannot be reproduced in contrast to ordinary buildings and objects. In the following article we focus on problem of flooding, repair and preventive measures in historical settlements. What kind of harm except mud and moist can the flood actually bring?

\section{Two Towns-Two Stories}

In the year 2002 there was a disastrous flood that affected very large areas in Western and South Bohemia. Among the damaged settlements were two which stories can nicely demonstrate success and failure in management and interdisciplinary approach during the flood and after. Although, these examples do not cover all the obstacles that flood repair work and prevention can bring, they represent several very important issues that have been discovered during the research and that might not be so obvious at the first sight.

\section{1. Český Krumlov}

Český Krumlov is located in the southern part of the Czech Republic near the Austrian border. The town is situated in the Vltava river valley in the foothills of the Blansky Forest Nature Reserve. It has an historical centre designated as a UNESCO World Heritage Site and which is the second largest castle complex in the Czech Republic. The Vltava River plays a crucial role in the setting and environment of the town. According to legend, the name Krumlov is derived from the German "Krumme Aue", which can be translated as "crooked meadow". The name comes from the natural topography of the town, specifically from the tightly-crooked meander of the river embracing the core of the town (Figure 1).

The setting of the town is the reason that floods are nothing unusual in this location. The most vulnerable part is the Inner Town. The back tracts of the houses lie right at the water level, and the river is a very important place-creating element. In the year 2002 the town experienced a disastrous flood that exceeded all expectations. More than half of the houses of the historical core were under the water up to the first floor. This represents about 300 houses in the historical core and about 800 houses in total were flooded. In some places, the buildings were under as much as 5 metres of water. Surprisingly most of them survived with no severe construc- 


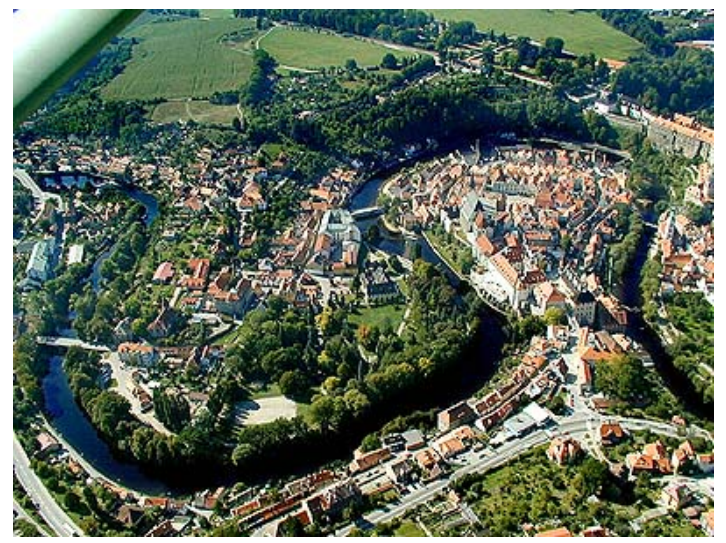

Figure 1. Meanders of the Vltava in Český Krumlov (source: Lubomir Mrázek).

tional problems. The greatest loss was noticed on interior equipment. We assume that houses were built with awareness of flood danger so the constructions were stable enough to survive. In the past, the ground floors of the buildings were usually used for service and work purposes, in order to minimize the losses when there was high water. Valuable property was kept in the upper floors. Nowadays, the ground level is usually used for commercial activities - shops, restaurants, hotels, art galleries, etc. These spaces are loaded with goods that are not tolerant to water damage.

The management immediately after the flood was very successful. Financial support arrived from everywhere. Many volunteers came to help with the clearance work. The local authorities immediately launched media campaigns. They gained the most from the fame of the town and its UNESCO status. However, later on the town hall decided to build vast flood protection system. Because of the cultural importance of the city, there was a big financial subvention from the government for these measures. The project was done very quickly with no participation of the public, no architectural competition. The administrative procedure was shortened to a minimum according to the requirement to spend the money as quickly as possible.

Immediately after works around the river bed started there has been a wave of resentment from public. People did not agree with scale of adaptation of the whole river area and visual and functional changes that it brings. Especially the ones living just by the river banks protested the most though they were also the most affected ones by the previous disaster. The river is a very important element in the town, and is fully involved in its life. Houses have their gardens by the riverside, and the river forms part of the living environment. Lowering the water was a major intervention to the historical setting. In addition, a small alluvial island was removed. Though it was not a real island, just a soil deposit, it has its place in historical portrayals of the town. There have been complains about esthetical impact of flood protection system in historical site and the UNESCO status is in danger. Furthermore, two years later another great problem appeared. 400 hundred years old houses are cracking and experiencing constructional problems. The river bed was deepened and widened to be able to absorb $\mathrm{Q}_{100}$ flood (i.e. quotation 100 which means that the probability of a flood of such severity occurring is 1 in 100 years). Due to these measures, the water level was reduced by about $80 \mathrm{~cm}$. Experts assume that lowering of water level about almost one meter causes changes in bedrock and therefore the foundations of the houses began to move (Figure 2). It is a very serious situation and now many experts gather together to solve the problem. All work has to be stopped. The whole project has to be revised and there seems to be a requirement for much more extra money to solve the problem.

\section{2. Švihov}

The second town that should be introduced here is Švihov in western Bohemia. It is a small town of village was hidden under the modern coating. All owners did cha-

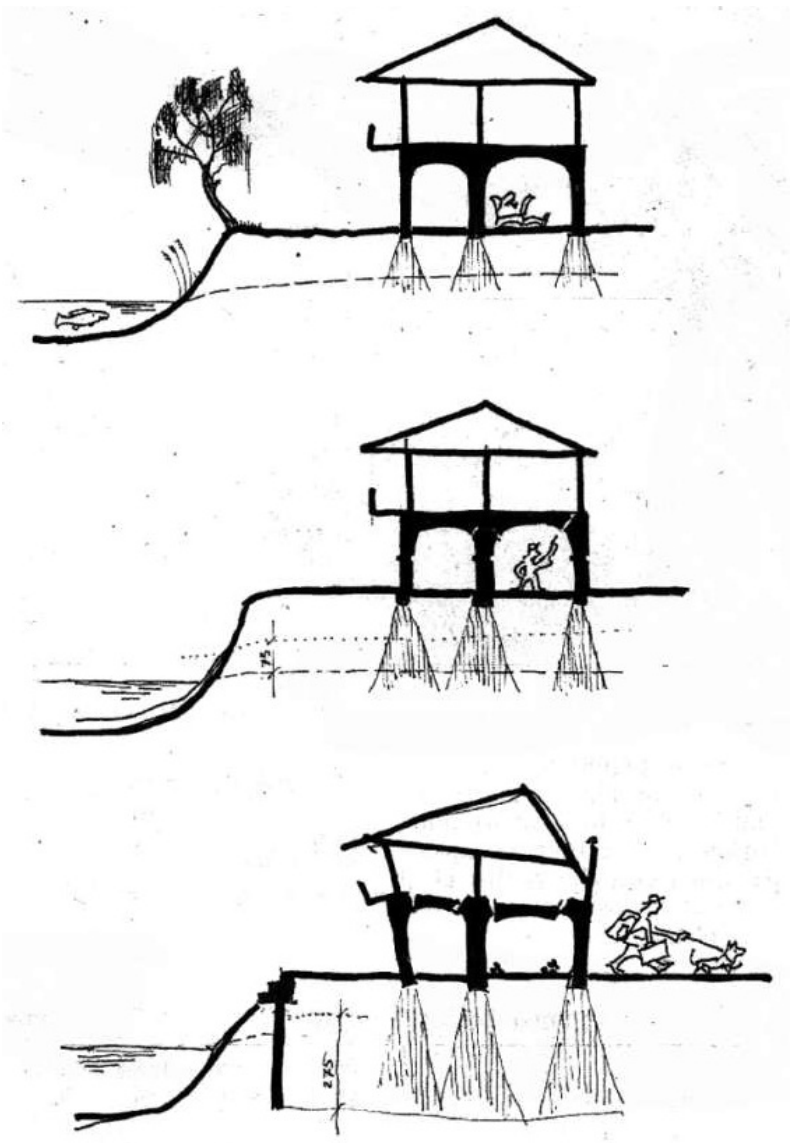

Figure 2. Changes in foundation soil caused by lowering the water level (source: Petr Pešek). 
racter situated in the valley of the river Úhlava. It is located about $30 \mathrm{~km}$ to the south of Pilsen, on the main road to Germany. A dominant feature of the town is Švihov Castle, a gothic water fortress (Figure 3). It is listed as a national cultural monument, and it attracts many tourists during the summer season. The river does not run through the center of Švihov but around in the meadows to the east of the town. The problem during high water is that the town center, including the castle, lies only slightly above the surrounding grassland, which serves as a natural inundation area. Floods are therefore an annual event. Every year there is a threat of flooding in spring and summer.

During the flood in 2002, Švihov was one of the most flood-affected towns in the Czech Republic. The town was damaged by flood with twice the volume of a $\mathrm{Q}_{100}$ flood. The depth of the river, which is normally about 1.5 $\mathrm{m}$ in this area, reached a level of about $5 \mathrm{~m}$. The width, which is normally $10 \mathrm{~m}$ was extended to about $400 \mathrm{me}-$ ters. There was about $1.8 \mathrm{~m}$ of water in the town center. Half of Švihov was under water. The streets and meadows were transformed into the bed of the flooded river. The castle itself has not been destroyed much as it is built to be water resistant from its origin. The situation was much worse in the town. About 30 houses had serious constructional defects. Their walls and ceilings needed to be supported. Finally 14 of them had to be demolished. The main problem with the most flood-affected houses was that they were built from unburned bricks. This material did not survive waterlogging, and collapsed. Most of the owners were not aware of the kind of structure that their best to save as much as they could, and in some cases they did almost the impossible to save their homes, whatever the financial cost.

Švihov is not as outstanding as Český Krumlov and financial resources were thus more difficult to find. Thanks to the good management and the personal commitment of the mayor, the town received millions of Czech crowns from EU funds, charity contributions and Czech Government support. The local authorities in Švihov started immediately on renewal and remediation. Within just two months after the flood, the Švihov Municipal Authority called on all relevant authorities, institutions and companies to take part in developing a flood protection study for Švihov (Figure 4). They were all working together on the project and developed two versions. The last word was then given to the public who decided to realize the more expensive but more architectural and historical friendly version. Instead of building new earth embankments the option of rehabilitation of the old fortification was chosen. Part of the discussion was also about where to find funding, as the castle-friendly version was ten times more expensive than the original suggestion of a protective rampart. With only one or two

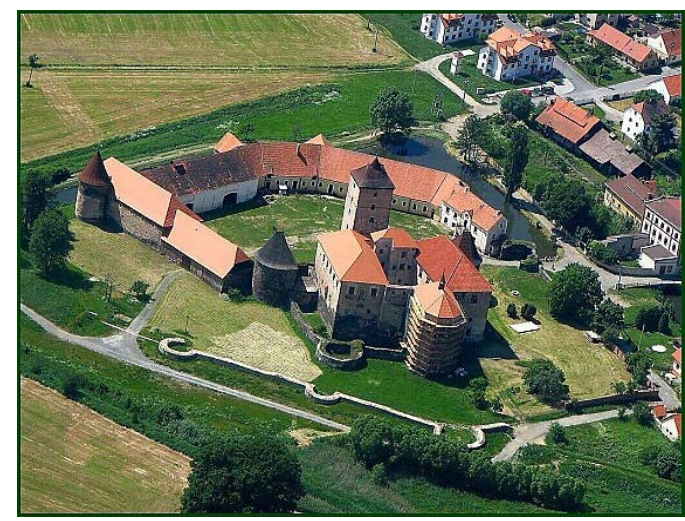

Figure 3. Reconstruction of the fortification wall.

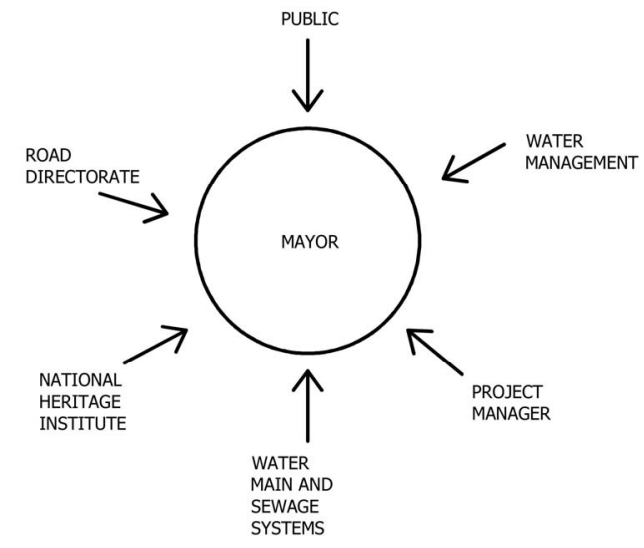

Figure 4. Subjects taking part in planning process (source: Klára Nedvědová).

exceptions, the residents of Švihov agreed that part of the money received from charitable collections should go for the project.

The old fortification wall was renewed and become a part of the flood protection rampart (Figure 3). The visible surface is made from stone masonry identical with the masonry of the castle. The wall is optically isolated from the rest of the barrier. It is brought tight together by a movable flood-protection barrier only when there is a flood threat. The castle water channel was locked by a new flood gate.

\subsection{Lessons Learnt}

The importance of public involvement in decision making was underestimated in Český Krumlov, and the river bed regulation project was not adequately publicized and discussed. In addition, the State Institute for Monument Protection made a mistake and misjudged the significance of the impact of the proposed adjustment on the historical appearance of the town. The project for the flood protection system should have been done more carefully. More time for preparation and analysing the situation would have been ultimately more efficient as well as including participation of experts from different 
fields of knowledge.

Contrary to this example we have an outstanding achievement in Švihov, where an interdisciplinary approach was applied during flood protection system planning. Additionally, the public was involved in the final decision making with great success. Furthermore, the old protective rampart has been restored, that would have probably never happened because of its financial cost unless being a part of flood protection. Failure in this case seems to be insufficient foreknowledge of owners and stakeholders about building construction and its vulnerability.

\section{Conclusions}

According to these two stories, our research project emerged as a visible need of integrated flood risk management with an interdisciplinary approach in planning of flood protection systems [1,2].

Rivers should not be seen only as a threat but also as a very important space-creating element, life source, connection and border between places. There is a great need of interdisciplinary approach in planning of flood protection systems where not only technical but also cultural, esthetical and historical point of view would go into account. We have to have in mind that each field of knowledge has only limited point of view but urban areas especially with cultural heritage on site are very complex systems that require also a complex approach to solve the flood problem. Otherwise, as we experienced in many case studies, including that of Český Krumlov presented here, there could be more harm done by flood protection system than by flood itself. If we want to effectively protect the historic environment against flooding we have to apply a much more sensitive and conscious approach.
Cooperation between experts from different domains has to be established to achieve the required outcome. A tendency towards adopting an interdisciplinary approach is nowadays present in many areas of study. Opening up for solving the problem from different points of view seems to be necessary if we want to be effective and successful, particularly in the case of flood protection of cultural heritage.

Here come some major points that we have learnt so far:

- Flood cannot be fully controlled but we can learn how to live with it and by complex integrated measures we can make water cooperate.

- There is a need for awareness of the value of cultural heritage on the site.

- There is a need for interdisciplinary dialogue in flood protection planning.

- It is important to access practical experience from floods in past years.

- One should learn from our ancestors.

- Transparency in legislative and processes of floodprotection planning is essential to achieve maximal efficiency and sensitivity.

- Do not underestimate the public opinion, and involve the public in the decision making process.

\section{REFERENCES}

[1] M. Drdácký, Ed., "Special Issue: Flood Impacts to Heritage Structures," Journal of Performance of Constructed Facilities, Vol. 24, No. 5, 2010, pp. 430-431.

[2] M. Drdácký, L. Binda, I. Ch. Hennen, Ch. Koepp, L. G. Lanza and R. Helmerich, Eds., "CHEF-Cultural Heritage Protection against Flooding," ITAM AS CR, v. v. i., Prague, 2011. 